
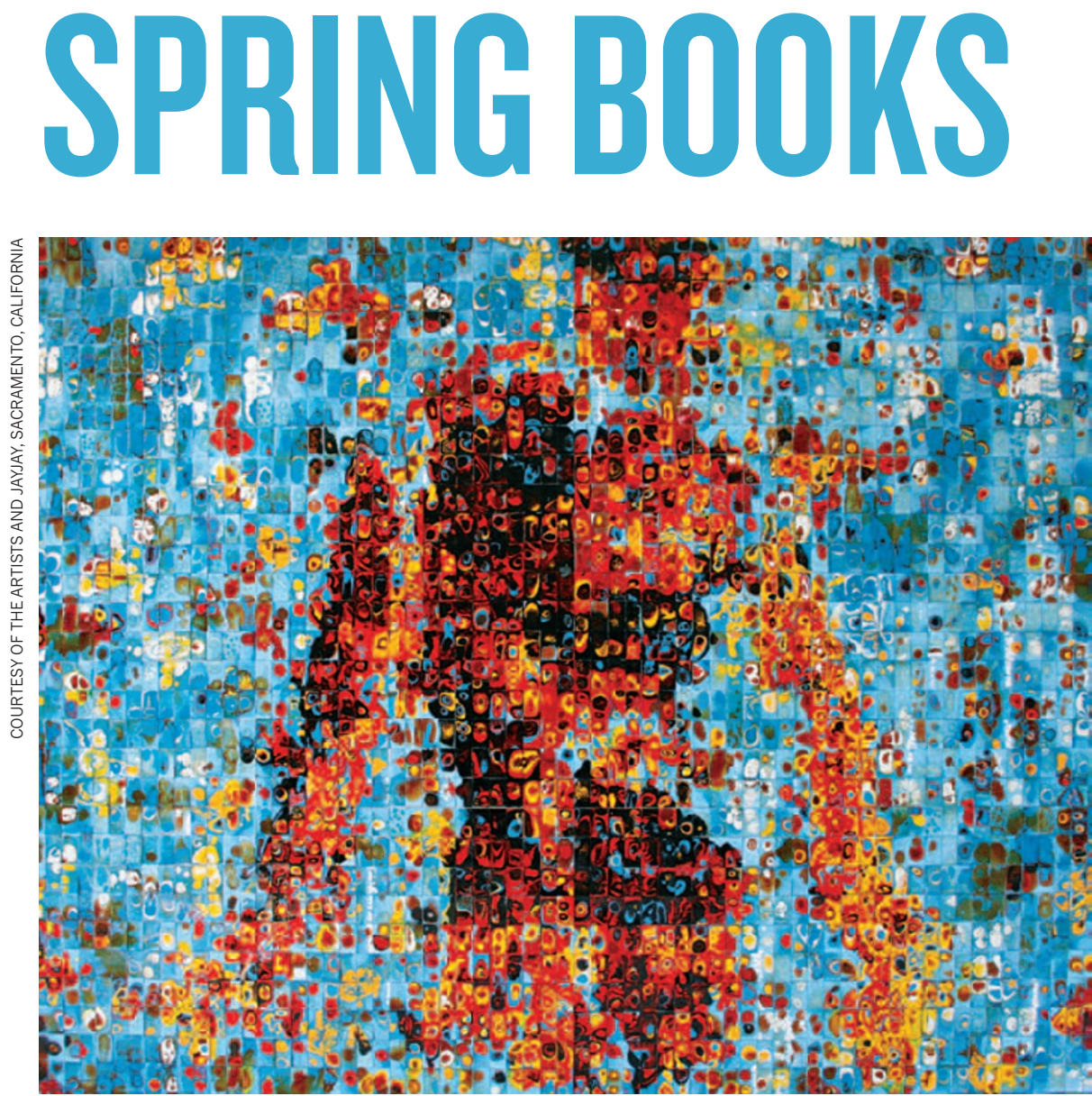

Size MAtters
San Jose Institute of Contemporary Art,
California.
Until 18 June 2011.
www.sjica.org
This Spring Books special issue
displays a selection of works from Size
Matters, an exhibition featuring ten
North American artists who address
ideas of size and scale. The works view
the world from unusual perspectives,
from lan Harvey and Koo Kyung
Sook's wall-sized enamel and shellac
mosaics of human figures to the
miniscule sculptures of Dalton Ghetti,
carved from the graphite points of
pencils. Expressed in a range of media,
including photographs, paintings
and video, the works comment on
biological building blocks, knowledge,
emotions and the environment.

Size Matters: Figure 2 (2007) by lan Harvey and Koo Kyung Sook.

BIOLOGY

\title{
A revolution in evolution
}

\section{Manfred Milinski enjoys Martin Nowak's paean to the power of cooperation to shape animal and human societies.}

$\mathrm{L}$ eading evolutionary theorist Martin Nowak sees cooperation as the master Aarchitect of evolution. He believes that next to mutation and selection, cooperation is the driving force at every level, from the primordial soup to cells, organisms, societies and even galaxies. Without cooperation, he says, our predecessors would still be RNA molecules. He sets out his groundbreaking ideas in SuperCooperators.

Co-authored with science journalist and editor of New Scientist Roger Highfield, SuperCooperators is part autobiography, part textbook, and reads like a best-selling novel. Nowak celebrates his oeuvre on the evolution of cooperation and challenges the mathematical basis for theories of kin selection and punishment. He is correct that this

part of evolutionary theory needs revisiting, but it is too soon to tell whether his bold ideas will hold up to empirical testing.

Game theory is central to Nowak's work and the book highlights five ways to work together for mutual benefit: direct reciprocity, indirect reciprocity, spatial games, group or multilevel selection and kin selection. Direct reciprocity is the tit-for-tat exchange of resources, which may be generous but is open to exploitation. Nowak believes that indirect reciprocity, where I help you and

DNATURE.COM

For another book review on cooperation, see: go.nature.com/82iaph someone else helps me, is the most important mechanism driving human sociality. It enforces the power of reputation, gained

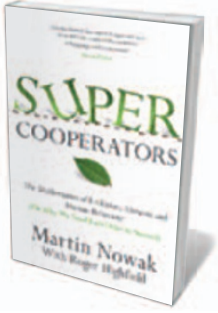

SuperCooperators: Altruism, Evolution, and Why We Need Each Other to

Succeed MARTINA. NOWAK WITH ROGER HIGHFIELD Free Press: 2011. 352 pp. $\$ 27$

by helping or refusing help, which is spread through gossip, thus selecting in evolutionary terms for sophisticated language. "Indirect reciprocity is the midwife of language and of our big, powerful brain," he says.

Cooperators can prevail through exchanges that are played out across and between networks and clusters of individuals, he explains. Multilevel or group selection follows among 